This article was downloaded by: [Memorial University of Newfoundland]

On: 30 January 2015, At: 17:48

Publisher: Routledge

Informa Ltd Registered in England and Wales Registered Number: 1072954

Registered office: Mortimer House, 37-41 Mortimer Street, London W1T

3J H, UK

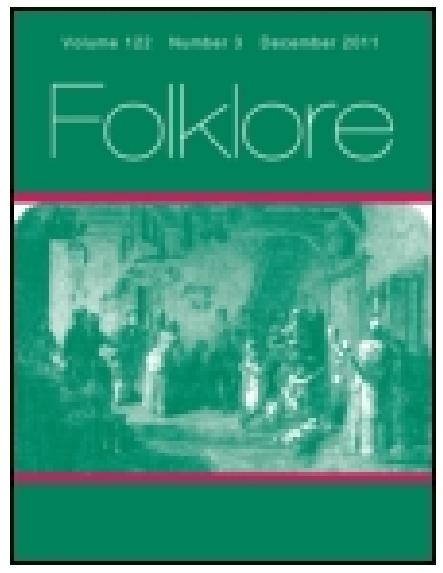

\title{
Folklore
}

Publication details, including instructions for authors and subscription information:

http:// www. tandfonline.com/loi/ rfol20

\section{The Sacred Fishes of Nant Peris}

M. J. Walhouse

Published online: 14 Feb 2012.

To cite this article: M. J. Walhouse (1897) The Sacred Fishes of Nant Peris, Folklore, 8:3, 281-285, DOI: 10.1080/ 0015587X.1897.9720423

To link to this article: http:// dx. doi. org/ 10.1080/0015587X.1897.9720423

\section{PLEASE SCROLL DOWN FOR ARTICLE}

Taylor \& Francis makes every effort to ensure the accuracy of all the information (the "Content") contained in the publications on our platform. However, Taylor \& Francis, our agents, and our licensors make no representations or warranties whatsoever as to the accuracy, completeness, or suitability for any purpose of the Content. Any opinions and views expressed in this publication are the opinions and views of the authors, and are not the views of or endorsed by Taylor \& Francis. The accuracy of the Content should not be relied upon and should be independently verified with primary sources of information. Taylor and Francis shall not be liable for any losses, actions, claims, proceedings, demands, costs, expenses, damages, and other liabilities whatsoever or howsoever caused arising directly or indirectly in connection with, in relation to or arising out of the use of the Content.

This article may be used for research, teaching, and private study purposes. Any substantial or systematic reproduction, redistribution, reselling, loan, sub-licensing, systematic supply, or distribution in any form to anyone is 
expressly forbidden. Terms $\&$ Conditions of access and use can be found at http://www.tandfonline.com/page/terms-and-conditions 


\section{MISCELLANEA.}

\section{The Sacred Fishes of Nant Peris.}

THE following extract from Bye-gones relating to Wales and the Marches, of the 25th November last, for which we are indebted to the courtesy of the Editor, deserves preservation in Folk-Lore:

"Two new fishes have just been put in the 'Sacred Well,' Efynon-y-Sant, at Tynyffynon, Nant Peris, Llanberis. Invalids in large numbers came, during the last century and the first half of the present century, to this well to drink of its ' miraculous waters,' and the oak box, where the contributions of those who visited the spot were kept, is still in its place at the side of the well. There have long been two 'sacred fishes' in this well, and there is a tradition in the village to the effect that if one of the Tynyffynon fishes came out of its hiding place when an invalid took some of the water for drinking, or for bathing purposes, cure was certain; but if the fishes remained in their den, the water would do those who took it no good. Two fishes only are to be put in the well at a time, and they generally live in its waters for about half $a$ century. If one dies before the other, it would be of no use to put in a new fish, for the ald fish would not associate with it, and it would die. The experiment has been tried. The last of the two fishes put in the well about fifty years ago died in August. It had been blind for some time previously to its death. When taken out of the water it measured $I 7$ inches, and it was buried in the garden adjoining the well. It is stated in a document of the year 1776 , that the parish clerk was to receive the money put in the box of the well by visitors. This money, together with the amount of 6s. 4 d., was his annual stipend."

\section{Ancient Custom at Sea.}

One of the most curious old customs I have ever seen is that known among sailors as "The burial of the dead horse."

When a sailor Joins a ship he is allowed one month's wages in 
advance, in order to buy what clothes he may need for the voyage When that month is up all the sailors collect together to "bury the dead horse," or, as it were, "the dead month." The ceremony can hardly be in its original form, but the following is what took place on board a ship bound from London to Melbourne, on which I was a passenger a short time ago, and I fancy it is very much the same on other sailing vessels.

In the morning one of the crew collected from the passengers as much money as they would give (in our case it amounted to $E \mathrm{I}$ los.) towards the "auction" of the dead horse in the evening. Then a horse was made, life-size; an empty tar-barrel stuffed with straw for body, wisp of tow for tail and mane, ears, eyes, and mouth imitated cleverly upon a stuffed head. The horse was well made, the crew being, like most sailors, clever with their fingers.

As soon as it was dark the fun began. One of the crew dressed as a jockey mounted the horse, and the two were pushed along the main deck in little jerks, followed by the whole crew in a long procession, singing the following doggrel in a slow chanting fashion :

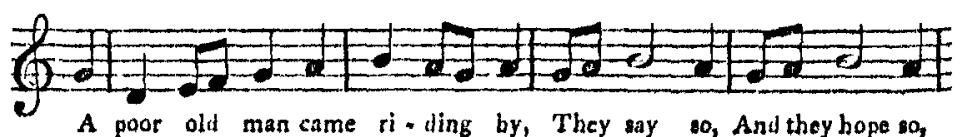

A poot old mancame ri-ding by, They say vo, And they hope so,

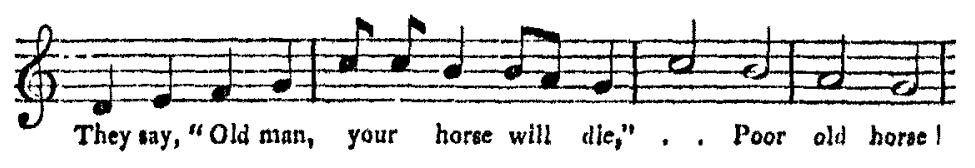

If he dies, I will tan his skin,

They say so, and they hope so,

If he lives, I will sell him again, poor old horse !

Old horse, old horse, what brought you here-

They say so, and they hope so,

Drawing turf for many a year,

Poor old horse !

From Ballycottin to Ballyack,

They say so, and they hope so,

Where I fell down and broke ny back,

Poor old horse I 
The poor old horse he's dead and gone,

They say so, and they hope so, And we will sing his funeral song, Poor old horse!

Ilis old hide good leather will make,

They say so, and they hope so,

And his flesh salt horse for sailor's sake, Poor old horse !

We will dig his grave with a silver spade,

They say so, and they hope so, And his memory shall never fade, Poor old horse!

We will lower him down with a golden chain,

They say so, and they hope so,

For his like we shall never see again,

Poor old horse!

After the song one of the crew, who was the auctioneer, proceeded to sell the horse by auction, the passengers bidding one against the other until the sum of $\mathcal{L}^{1}$ Ios. was reached. $\Lambda \mathrm{t}$ this point we had been cautioned to stop bidding, unless we intended to pay the extra sum out of our own pockets. One lady bid a few shillings higher-the bargain was struck, and the auction over. All this had taken some time, and was made amusing by the auctioneer, who was a witty fellow. No attempt was made to present the lady with her property. A blue light was lit, and the jockey, still seated on the horse, was drawn up by a rope to the end of the yard-arm, where they dangled for some time over the dark sea. The jockey lit another blue light and waved it aloft ; it burnt brilliantly, sending sparks flying all around into the darkness. We then all gave "three cheers for the dead horse," the jockey cut a rope, the horse fell with a splash into the sea, and was quickly left far behind; a curious sight in mid-ocean for any other passing ship. After that, the jockey was hauled down, and the captain ordered the stewards to " serve out grog all round." The latter part of the evening was devoted to a concert and recitations on the main deck, together with some very clever stepdancing by the jockey. He was a small man, light and agile as a girl, and his dancing, in his rough shoes and on that uneven deck, was as pretty as any seen on a stage. Throughout the evening the moon shone as brilliantly as it only can shine out on the open sca. Those who have been lucky enough to see such 
moonlight under such circumstances will understand how it added to the effect of the curious proceedings of which we had been the witnesses.

At ro p.m. "God save the Queen" was sung, and so ended "The burial of the dead horse." "

Evelyn A. Melvill Richards.

The Rectory, Rayleigh, Essex.

\section{SNAKE-STONES.}

Ancient stones carved with representations of serpents (always the cobra) are very numerous in the south of India, often in groups on a platform under a tree or within the precinct of a temple, often too singly by a road-side; or in the corner of a field, purposely left waste for the local deities, like the "goodman's croft" in Scotland; sometimes by a well or spring on a hill-side. These serpent-stones, very various in design, abound especially throughout the Mysore territory. Some antiquaries think them as old as the prehistoric monuments, cromlechs, kistvaens, \&c., which are also very numerous. Most of them have an appearance of extreme antiquity, worn, blurred, and weatherbeaten, as in the example on the table. Indeed, it seems not improbable that they may be vestiges of the popular cult previous to the Aryan invasion. No priest bas charge of them; no Brahman assists in any serpent rites; Brahmans avoid the sight of a snake, and meeting one is for them the worst of omens, and enough to stop any undertaking. In the north of India, serpent-stones, I believe, do not exist. The Brahmans in their descent from north to south probably found serpent-worship popular and flourishing, and from motives of policy countenanced it to a certain extent, but never adopted it. In connection with the Brahmanical gods the serpent is always shown in a subordinate or servile capacity, seven-headed, and overshadowing Shiva or Vishnu like a canopy, or hung about them necklace-fashion.

At present the village people regard these old weather-worn stones with a certain awe and superstitious feeling. None will point a finger at them, as it is believed that a finger so pointed would rot and drop from the hand. Men make them no offerings, but childless women often lay fowers before them and touch 
their heads with red paint, hoping thereby to be blessed with children. I have often seen flowers laid before this stone, which was placed in a niche by a spring on the side of a picturesque wooded bank above a temple near Mangalore, the principal town of Canara, on the western coast of India. I understood that offerings and adjurations were especially made to the side of the stone bearing the rude sculpture of a serpent-woman, which recalls the Melusina of medirval romance. $A$ vast amount of ancient symbolism is gathered round this form. In early Christian ages, amongst that pre-eminently mystical sect the Gnostics, the serpentWoman typified the world-soul, the third creative power, whence issued matter from which man was formed. That strange bewildering system almost certainly reached Egypt and Iurope from the East. I could not learn, however, that any popular stories like the Melusina romance-legends are current regarding these snake-woman figures in India to-day.

It may be mentioned that some regard the serpent-stones as relics of that Scythian invasion of which a dim tradition survives, and which at some unrecorded time preceded the advent of the Aryan tribes. Some of the stones bear a snake on one side and on the other a figure in what looks like the ancient Scythic costume of high cap and tunic, such as would befit a cold country, resembling nothing worn by Hindus.

I may add, lastly, one extraordinary bit of folklore belief with respect to the cobra and snake-stones. The Rev. G. Richter, a missionary long resident in Coorg, reports that in that small principality, situate between Canara and Mysore, it is popularly believed that the cobra lives a thousand years; at middle life its body begins to shrink and brighten till it shines like silver, and measures three feet or less at the age of six or seven hundred years ; later on it shines like gold, and is only a foot in length; at last it shrinks to the size of a finger. Then one day it flies up in the air, dies, falls to the ground, and disappears, but presently a serpent-stone appears upon the spot, which is called Naka, and enclosed with stones; anyone stepping upon it, even unawares, will be attacked by incurable skin-disease, and rot away by degrees. Down further south the natives have a strange notion that a cobra dying turns into a partridge; and everywhere when spoken of it is termed "the good snake," like "the good people" in Ireland and Scotland, and the Eumenides in antiquity.

M. J. Walmousen 